\title{
INFLUENCE OF AMELIORATION ON THE PRODUCTIVITY OF ALFALFA ON ACID SOIL TYPES VERTISOLS
}

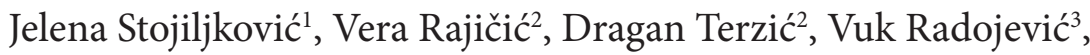 \\ Nenad Đurić ${ }^{4}$, Nataša Ljubičićc ${ }^{5}$ Vera Popovićc ${ }^{3 *}$
}

\begin{abstract}
Alfalfa is the most important forage legume in our agroecological conditions for feeding cattle. In the area of Jablanica district, alfalfa occupies a considerable place in the total plant production. The restrictive factor in the establishment and short durability of alfalfa stand is the low $\mathrm{pH}$ of arable agricultural soil. Within the three-year field trial on Vertisol soil type ( $\mathrm{pH}$ in $\mathrm{KCl}$ 4.9), from 2016 to 2018 , alfalfa plot yield has been analyzed with different fertilization variants. The research results indicate that alfalfa provides a significantly higher yield on the plot where amelioration measures were applied, through the application of limestone and manure, with the addition of mineral fertilizer. A barely lower yield was achieved on the calcified and manured plot, while the lowest yield was on the control plot, where a generous amount of mineral fertilizer was added, which is a common practice of agricultural producers in the area of Jablanica district.
\end{abstract}

Key words: calcification, Medicago sativa L., soil acidity, yield

\section{Introduction}

The most significant perennial legume in the agro-ecological conditions of Serbia is alfalfa (Medicago sativa L.), which is characterized by a high yield of very good quality herbage. It has a beneficial effect on the physical, chemical and biological properties of the soil (Lakić et al., 2018). Agricultural production is more and more at the centre of a complex set of ecosystem-threatening problems (FAO, 2007). During the second half of the $20^{\text {th }}$ century, more attention is paid to the quality of the environment, and takes a very high place in the value system of both individuals and society as a whole (Jelić et al., 2013; 2015). In the structure of the total used agricultural land of the Republic of Serbia, intensive ways of using of arable soil prevail (Karapandžin and Bošnjak, 2014), thus affecting the additional impact on soil resources which is reflected in the loss of organic matter, soil compaction and deterioration. The application of large amounts of mineral fertilizers and pesticides, which are considered environmental pollutants, as well as the poor management of crop residues and insufficient application of organic fertilizers, makes soil degraded and its fertility significantly decreased (Đekić et al., 2014; Jelić et al., 2017; Gudžić et al., 2019; Popović et al., 2019; Terzić et al., 2019; Rajičić et al., 2020). The above-mentioned reasons require changes in traditional agriculture activities, which will lead to a reduced negative impact on the environment.

\footnotetext{
Original Scientific Paper (Originalni naučni rad)

${ }^{1}$ Stojiljković J, Agricultural Advisory and Expert Service, Jug Bogdana 8a, 16000 Leskovac, Serbia;

${ }^{2}$ Rajičić V, Terzić D, University of Niš, Faculty of Agriculture, Kosančićeva 4, Kruševac, Serbia;

${ }^{3}$ Radojević V, Popović V, Institute of Field and Vegetable Crops, Maksima Gorkog 30, Novi Sad, Serbia;

${ }^{4}$ Đurić N, John Nezbit University, Faculty of Biofarming, Bačka Topola, Serbia;

${ }^{5}$ Ljubičić N, Biosense Institute, Novi Sad, Serbia;

*e-mail: drvvpopovic@gmail.com, bravera@eunet.rs
} 
Alfalfa is a perennial legume, and the period of its exploitation is 5 to 7 years. A big problem in the establishment and short durability of alfalfa stands is the low $\mathrm{pH}$, which in the area of Jablanica district is a restrictive factor for successful production and long-term. This culture is very sensitive to soil acidity, therefore certain types of soil (pseudogley, podzolized grove, deluvial and similar soils) are not suitable for its growing. If repair measures are not applied on such soils, and the introduction of larger quantities of manure and mineral fertilizers is omitted (add CAN), such plots cannot give favourable cultivation results. Acidic soils are poor in calcium and are therefore more or less unfavourable for growing alfalfa. The problem of soil acidification will become more pronounced as a result of acid rain, long-term $\mathrm{N}$ fertilization (Robson and Bottomley, 1991). Alfalfa can be grown on slightly acidic soils if land reclamation is performed and humidity regulation and calcification with regular application of organic and mineral fertilizers are done before planting. Acid reaction soils are characterized by low microbiological activity and the rhizosphere is limited to a shallow surface zone, thus with increasing acidity, the biomass of microorganisms decreases (Popović et al., 2019; Terzić et al., 2019; Lakić et al., 2018; 2019; 2019). The research conducted throughout many years in the Agricultural Advisory and Expert Service shows that acid soils occupy significant areas (70-80\% of arable land).

The three-year research aimed to determine the effect of calcification and manure application on fertility and $\mathrm{pH}$ of the soil, as well as, alfalfa productivity in the Jablanica district.

\section{Material and methods Experimental design}

During the period from 2016 to 2018, a field experiment was conducted on the property of the village Kacabać, which belongs to Bojnik

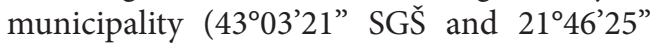
IGD, $219 \mathrm{~m}$ altitude), on Vertisol soil type ( $\mathrm{pH}$ in $\mathrm{KCl} 4.92$ ). The field experiment was set up according to a randomised block design, in three replications. The elementary plot size was
$30 \mathrm{~m}^{2}(6 \times 5 \mathrm{~m})$. For the needs of the research, the following fertilization treatments were applied: V1 - $5 \mathrm{t} \mathrm{ha}^{-1}$ lime $+25 \mathrm{t} \mathrm{ha}^{-1}$ manure; V2 - NPK 8:24:16 $350 \mathrm{~kg} \mathrm{ha}^{-1}+5 \mathrm{t} \mathrm{ha}^{-1}$ lime $+25 \mathrm{t}$ ha $^{-1}$ manure and V3 - control plot NPK 8:24:16 $500 \mathrm{~kg} \mathrm{ha}^{-1}$. Hydrated lime with a $\mathrm{CaO}$ content of $70 \%$ was used as a fertilizer for calcification. Before the sowing of alfalfa "NS Mediana ZMS V", soil samples were taken to determine the most important agrochemical characteristics of the soil.

In the year of planting with basic cultivation, the mineral fertilizer, lime, and manure were plowed, depending on the variant of treatments. Sowing was done with a manual sower, in the second decade of September, with a seed quantity of $18 \mathrm{~kg} \mathrm{ha}^{-1}$.

\section{Meteorological conditions}

Climatic parameters were obtained from the meteorological station in Bojnik. The average monthly temperatures and precipitation during the research years are shown in Table 1.

Throughout all three years of the research, the average monthly temperature increased from April to July. The lowest average temperature was measured in $2016\left(12.11^{\circ} \mathrm{C}\right)$, while the highest average temperature during the research period was measured in $2018\left(13^{\circ} \mathrm{C}\right)$. Average annual temperatures were slightly higher than the multi-year average.

During the research period, distinctions were observed not only in terms of total precipitation during the vegetation period but also in terms of precipitation distribution by months. The highest amount of precipitation was recorded during 2016 (809 $\mathrm{mm})$, and the lowest during 2017 (706 mm). In 2018, the measured amount of precipitation was 753 $\mathrm{mm}$, with $114 \mathrm{~mm}$ of precipitation falling in July, which is $46.62 \mathrm{~mm}$ more than the multi-year average, which resulted in slightly lower yield of alfalfa. Sufficient precipitation in the spring is highly significant for successful alfalfa production. Observing the average monthly air temperatures in combination with the amount and distribution of precipitation by months during the three-year examination, it can be 
Table 1. Average monthly air temperatures and precipitation, Bojnik, Serbia

Tabela 1. Prosečne mesečne temperature i padavine, Bojnik, Srbija

\begin{tabular}{crrrrrrrr}
\hline \multirow{2}{*}{ Months } & \multicolumn{2}{c}{$\mathbf{2 0 1 6}$} & \multicolumn{2}{c}{$\mathbf{2 0 1 7}$} & \multicolumn{2}{c}{$\mathbf{2 0 1 8}$} & \multicolumn{2}{c}{ Multi-year average } \\
\cline { 2 - 9 } & $\mathbf{T}$ & $\mathbf{P}$ & $\mathbf{T}$ & $\mathbf{P}$ & $\mathbf{T}$ & $\mathbf{P}$ & $\mathbf{T}$ & $\mathbf{P}$ \\
\hline I & -1.40 & 84 & -5.80 & 44 & 3.20 & 48 & 0.96 & 52.96 \\
\hline II & 8.56 & 50 & 9.20 & 49 & 3.70 & 55 & 2.13 & 45.96 \\
\hline III & 7.67 & 93 & 10.30 & 39 & 7.10 & 131 & 7.17 & 52.58 \\
\hline IV & 13.73 & 24 & 11.30 & 69 & 14.20 & 43 & 11.90 & 68.78 \\
\hline V & 14.70 & 70 & 16.70 & 82 & 19.10 & 91 & 16.59 & 66.48 \\
\hline VI & 21.90 & 63 & 21.90 & 19 & 20.90 & 88 & 20.15 & 55.89 \\
\hline VII & 22.80 & 114 & 23.50 & 34 & 22.30 & 78 & 22.69 & 67.38 \\
\hline VIII & 21.40 & 30 & 23.30 & 20 & 23.00 & 46 & 22.33 & 43.08 \\
\hline IX & 17.90 & 56 & 18.70 & 20 & 18.40 & 92 & 17.14 & 47.15 \\
\hline X & 11.90 & 82 & 12.60 & 117 & 14.20 & 5 & 11.40 & 60.92 \\
\hline XI & 6.80 & 131 & 7.00 & 73 & 7.70 & 57 & 7.14 & 53.00 \\
\hline XII & -0.70 & 12 & 4.00 & 140 & 2.20 & 19 & 1.96 & 57.88 \\
\hline Average & 12.11 & 809 & 12.73 & 706 & 13.00 & 753 & 11.80 & 672.06 \\
\hline
\end{tabular}

$\mathrm{T}$ - temperature; $\mathrm{P}$ - precipitation

concluded that the thermal conditions were the most favourable during the 2018 production year. On the other hand, the year 2016 had the most precipitation and was the worst for alfalfa production.

\section{Statistical analysis}

The results were analysed by two-factorial analysis of variance (ANOVA) using the statistics module Analyst Program SAS/STAT (SAS Institute, 2000). The significance of differences in mean values of the treatments was tested by the LSD test.

\section{Results and discussion Chemical composition of soil}

Table 2 shows the chemical composition of the soil before alfalfa planting ( $\mathrm{Y} \times \mathrm{E}$ ) and on the plot where reclamation repair measures were made (RM). The experiment was done on Vertisol type of soil, characterized by heavy mechanical composition and moderate fertility. Agrochemical analysis of the soil in the laboratory of PSSS Leskovac determined that it is acidic soil with poor concentration of humus and nitrogen, as well as phosphorus, but rich in potassium. Agrochemical analysis of the soil was done according to standard methods.

Table 2. Chemical composition of soil in the year of establishment of alfalfa crops (YE) and the third year, on the plot where reclamation repair measures (RM) were made

Tabela 2.Hemijska analiza zemljišta u godini zasnivanja useva lucerke (YE) i u trećoj godini, na parceli gde su rađene miliorativne popravke zemljišta

\begin{tabular}{|c|c|c|c|c|c|}
\hline & \multicolumn{5}{|c|}{ Parameters (at depths of $0-30 \mathrm{~cm}$ ) } \\
\hline & Humus \% & Total nitrogen $\%$ & $\mathrm{P}_{2} \mathrm{O}_{5} \mathrm{mg} 100 \mathrm{~g}^{-1}$ & $\mathrm{~K}_{2} \mathrm{O} \mathrm{Mg} 100 \mathrm{~g}^{-1}$ & $\mathrm{pH}$ in $\mathrm{KCl}$ \\
\hline YE & 2.1 & 0.10 & 8.0 & 21.0 & 4.9 \\
\hline RM & 2.9 & 0.14 & 12.0 & 22.5 & 5.8 \\
\hline
\end{tabular}


The effect of fertilization and reparation of physical and chemical properties of soil on alfalfa yield was monitored during the threeyear research. (Table 2). According to the agrochemical analysis of the soil in the third year, it was determined that by applying ameliorative measures and repairing the acidity of the soil that has bad chemical properties, alfalfa can be successfully grown. After the agrochemical analysis of the soil in the third year, it was concluded that the application of lime fertilizer and manure visibly reduced soil acidity (from 4.90 it was improved to 5.80), furthermore, both humus and total nitrogen content were improved, phosphorus availability was increased, the soil was better aerated, which resulted in a high yield of alfalfa. Soils that are exposed to a higher level of precipitation throughout the year, primarily due to climatic characteristics, are more susceptible to acidification. That is a common situation, particularly in mountainous areas, due to which the soil becomes very acidic. Human activity can also affect soil acidity. Long-term inadequate application of mineral fertilizers can also significantly affect soil acidity. Also, long-term use of urea contributes to soil acidification (Popović et al., 2019; 2020; Rajičić et al., 2020). The problem of acid soils is significantly important for soils in southern Serbia. Taking into consideration the fact, that acid soils cover an increasing part of agricultural land, the production capacity is significantly reduced. Reduced intake of organic matter combined with the increasing use of exclusively mineral (nitrogen) fertilizers have also contributed to the more intensive process of soil acidification over the past decades (Đekić et al., 2014; Jelić et al., 2017; Gudžić et al., 2019; Terzić et al., 2019; Rajičić et al., 2020). Soil acidity affects crop sprouting, early germination, and total biomass production, that is, the production of dry matter of roots and aboveground parts (Zhang et al., 2004, 2006).

Also, the agrochemical analysis was performed on the content of $\mathrm{P}_{2} \mathrm{O}_{5}$ and $\mathrm{K}_{2} \mathrm{O}$ on the plot where a larger amount of mineral fertilizer was applied, and slightly small differences in the content of easily accessible $\mathrm{P}_{2} \mathrm{O}_{5}$ and $\mathrm{K}_{2} \mathrm{O}$ were noticed.
The use of manure helps the soil get back the nutrients taken by the yield. Manure is an organic fertilizer, which is a mixture of solid and liquid limbs of animals and mats, which is subjected to turbulence processes. Manure is usually said to be a complete fertilizer, unlike mineral fertilizers which are complementary, that is incomplete. By applying organic fertilizers, activity of beneficial microorganisms into the soil is improved. By decomposition, the introduced organic matter is partially mineralized, but new high-molecular organic compounds - humic substances - are synthesized from the products of decomposition. Humus is extremely significant in the soil because it affects the entire dynamics and all the properties of the soil, and that is the reason why it is called the regulator of soil fertility. The action of manure makes heavy soils looser, and the interval of moisture retention is extended, making the soil more suitable for cultivation. The power of water retention increases, as well as the amount of accessible water in the soil, plus the absorption properties of the soil improves.

\section{Alfalfa yield}

Field trials supposed to enable selection of the most successful genotypes which is critical because of the existence of Genotype by Environment interaction. To assess this interaction we are forced to conduct field trials in several environments and/or years (Vasileva, Kostov, 2015; Babić et al., 2019; Ugrenović et al., 2019; Mandić et al., 2020).

The research results in Table 3 indicate that alfalfa reacts with a significantly higher yield on the plot where calcification was performed (application of manure with the addition of mineral fertilizer). A slightly lower amount of yields were achieved on the plot where the land was calcified and repaired with manure without the application of mineral fertilizers, while the lowest yield was achieved on the control plot where it was fertilized only with mineral fertilizers. Also, higher yields were achieved with the first and second variant of 
fertilization in the second and third year of the experiment than in the first year.

Numerous researches in our country, as well as throughout the world, indicate that adequate application of lime materials in combination with organic and mineral fertilizers is the most efficient way to eliminate unfavourable production properties of those soils with poor physical and chemical properties (Jelić et al., 2013; Rajičić et al., 2020). There is an increasing need for the determination of fertilization and cultivation systems that will be adapted to both the soil and climatic conditions of all production areas with acid lands (Stevović et al., 2010; Đekić et al., 2014; Jelić et al., 2015; Terzić et al., 2018; Gudzic et al., 2019; Popović et al., 2019; Biberdzic et al., 2020; Rajičić et al., 2020).

The results obtained by the research indicate the possibility of expanding areas and the durability of alfalfa on acidic soils in the Jablanica district. Reclamation fertilization has reduced the acidity of the soil, improved the structure of the soil, thus achieving a favourable effect for growing alfalfa, which consequently affects the longer use of alfalfa soil and higher yields.
According to Rechcigl et al. (1985), the application of $\mathrm{Ca}$ can lead to an increase in $\mathrm{pH}$ and a significant decrease in the concentration of Al. The same authors claim that even during application (without processing 6-18 months before sowing), the yield of alfalfa's dry matter increased 2-3 times. By applying only mineral fertilizer, the content of easily accessible $\mathrm{P}_{2} \mathrm{O}_{5}$ and $\mathrm{K}_{2} \mathrm{O}$ was improved, but the physical properties of the soil and the acidity of the soil were not improved, which is not a long-term solution.

Based on the analysis of variance, it can be concluded that there are highly significant differences in yield in regard to the fertilization of investigation $\left(\mathrm{F}=250.379^{* *}\right)$. Based on the analysis of variance, it can be concluded that there are no significant differences in yield at investigated years (Table 4). The interaction of the investigated factors (Y x G) exhibits was no significant effect on yield ( $p>0.05)$. The present results confirm the opinion of many authors that the traits analyzed are genetically determined but are strongly modified by the environment and weather conditions (Jelic et al., 2017; Terzic et al., 2018; Popović et al., 2019; 2020).

Table 3. Alfalfa yield in a three-year study

Tabela 3. Prinos lucerke u trogodišnjim ispitivanjima

\begin{tabular}{cccrcrrrr}
\hline \multirow{2}{*}{ Variant } & \multicolumn{2}{c}{$\mathbf{2 0 1 6}$} & \multicolumn{2}{c}{$\mathbf{2 0 1 7}$} & \multicolumn{2}{c}{$\mathbf{2 0 1 8}$} & \multicolumn{2}{c}{ 2016-2018 } \\
\cline { 2 - 9 } & $\bar{x}$ & Sd & $\bar{x}$ & Sd & $\bar{x}$ & Sd & $\bar{x}$ & Sd \\
\hline V1 & $12.493^{\text {ab }}$ & 1.391 & $13.770^{\mathrm{b}}$ & 0.465 & $13.893^{\mathrm{b}}$ & 0.392 & $13.386^{\mathrm{b}}$ & 1.013 \\
V2 & $13.233^{\mathrm{a}}$ & 1.288 & $17.098^{\mathrm{a}}$ & 0.842 & $17.285^{\mathrm{a}}$ & 0.869 & $16.872^{\mathrm{a}}$ & 1.008 \\
V3 & $6.003^{\mathrm{c}}$ & 1.074 & $6.928^{\mathrm{c}}$ & 0.948 & $7.103^{\mathrm{c}}$ & 0.552 & $6.678^{\mathrm{c}}$ & 0.923 \\
Average & 11.577 & 4.613 & 12.599 & 4.541 & 12.761 & 4.523 & 12.312 & 4.413 \\
\hline
\end{tabular}

$\bar{x}$ - average value; Sd - standard deviation; V1 - $5 \mathrm{t} \mathrm{ha}^{-1}$ lime $+25 \mathrm{t} \mathrm{ha}^{-1}$ manure; V2 - NPK 8:24:16 $350 \mathrm{~kg} \mathrm{ha}^{-1}$ $+5 \mathrm{t} \mathrm{ha}^{-1}$ lime $+25 \mathrm{t} \mathrm{ha}^{-1}$ manure and V3-control plot NPK 8:24:16 $500 \mathrm{~kg} \mathrm{ha}^{-1}$

Table 4. The analysis of variance for the alfalfa yield

Tabela 4. Analiza varijanse prinosa lucerke

\begin{tabular}{lccccc}
\hline Effect & df & Mean sqr Effect & Mean sqr Error & F & p-level \\
\hline Year (Y) & 2 & 7.418 & 3.709 & 0.178 & 0.838 \\
Fertilization (F) & 2 & 483.177 & 241.589 & $250.379^{* *}$ & $0.000^{* *}$ \\
(YxF) & 4 & 0.172 & 0.043 & 0.050 & 0.995 \\
Error & 18 & 15.567 & 0.865 & & \\
\hline
\end{tabular}

${ }^{\mathrm{ns}}$ non significant; ${ }^{*}$ significant at 0.05 ; ${ }^{* *}$ significant at 0.01 ; 


\section{Conclusions}

The highest yield of Alfalfa was achieved on the plot on which, besides basic fertilization, ameliorative repair of acidic soil was performed.

Reclamation fertilization has reduced the acidity of the soil. Furthermore, it has improved the content of humus and total nitrogen, as well as the structure of the soil, thus achieving a favourable effect for Alfalfa cultivation, which has a positive impact on longer utilization of Alfalfa and higher yields.

Three-year research determined that by applying ameliorative measures and repairing the acidity of the soil which has chemical properties, Alfalfa can be successfully grown in the area of Jablanica district.

It is of great significance that during the educational processes, agricultural producers are properly educated on how to preserve the quality of the living environment, without compromising their production. Agricultural producers, at the level of the individual in a global context, can reduce the negative impact of agricultural production on the environment.

\section{Acknowledgements}

This paper is part of the projects, Grant numbers: 451-3-9/2021-14/200383, 200032 and 200358, financed by the Ministry of Education, Science and Technology Development of the Republic of Serbia and the Bilateral Project Republic of Serbia and Montenegro 2019-2021: Alternative cereals and oil crops as a source of healthcare food and an important raw material for the production of biofuel.

\section{References}

Babić M, Čanak P, Vujošević B, Babić V, Stanisavljević D (2019). Significance of field trials data cleaning process for making more reliable breeder decisions. Selekcija i semenarstvo, 25 (2): 23-30.

Biberdzic M, Barac S, Lalevic D, Djikic A, Prodanovic D, Rajicic V (2020): Influence of soil tillage system on soil compactionand winter wheat yield. Chilean Journal of Agricultural Research, 80 (1): 80-89.
Đekić V, Milovanović M, Popović V., Milivojević J., Staletić M, Jelić M, Perišić V (2014): Effects of fertilization on yield and grain quality in winter triticale. Romanian Agricultural Research, 31: 175-183.

FAO - Food and Agriculture Organization of the United Nations (2007): The State of Food and Agriculture, Paying Farmers for Environmental Services. Rome. ISBN 97892-5-105750-6

Gudzic S, Sekularac G, Djikic A, Đekić V, Aksic M, Gudzic S (2019): The impact of the long-term fertilisation with mineral fertilisers on the chemical properties of Vertisol (central Serbia). Applied Ecology and Environmental Research, 17 (5): 12385-12396.

Jelić M, Dugalić G, Milivojević J, Đekić V (2013): Effect of liming and fertilization on yield and quality of oat (Avenasativa L.) on an acid luvisol soil. Romanian Agricultural Research, 30: 249-258.

Jelic M, Milivojević J, Nikolic O, Đekić V, Stamenkovic S (2015): Effect of long-term fertilization and soil amendments on yield, grain quality and nutrition optimization in winter wheat on an acidic pseudogley. Romanian Agricultural Research, 32: 165-174. Jelić M, Đekić V, Đalović I, Dugalić G, Knežević D, Gudžić N (2017): Influence of fertilization and liming on changes of agrochemical characteristics of soil type pseudogley. VIII International Scientific Agriculture Symposium "Agrosym", Jahorina, October 05-08, 2017; 1839-1845.

Karapandžin J and Bošnjak D (2014): Comparative Analysis of Land Capacity of the Republic of Serbia and the Countries of the EU. Thematic proceedings. International Scientific Conference Sustainable Agriculture and Rural Development in Terms of Republic of Serbia Strategic Goals Realization Within the Danube Region - Rural development an (un) limited resources, 699-716.

Lakić Ž., Glamočlija Đ., Kondić D., Popović V., Pavlović S. (2018): Krmne biljke i žita u funkciji zaštite zemljišta od degradacije. Monografija. Banja Luka, ISBN 978-9993893-47-9, 1-403. 
Lakić Ž., Antić M., Đurđić I., Popović V. (2019): Morphological caracteristics of alfalfa genotypes tolerant of low soil pH.Genetika, 51 (3): 907-922. https://doi.org/10.2298/ GENSR1903907L

Lakić Ž, Predić T, Đurđić I, Popović V (2020): Recultivation of degraded soil due to mining activity without adding organic layers of soil using Alfalfa and mixtures of grass legumes. Agriculture and Forestry, 66(4): 223-237.

Mandić D, Pržulj N, Đurašinović G, Jovović Z (2020): Julija-nova sorta ozime pšenice. Julija-New variety of wheat. Selekcija i semenarstvo, 26 (2): 15-20.

Popović V, Stevanović P, Vučković S, Ikanović J, Rajičić V, Bojović R, Jakšić S (2019): Influence of CAN Fertilizer and Seed Inoculation with NS Nitragin on Glycine max Plant on Pseudogley Soil Type. Agriculture Conspectus Scientificus, 84 (2): 165-171.

Popovic V, Ljubičić N, Kostić M, Radulović M, Blagojević D, Ugrenovic V, Popovic D, Ivosevic B (2020): Genotype x Environment Interaction for Wheat Yield Traits Suitable for Selection in Different Seed Priming Conditions. Plants. 9 (12): 1804; https:// doi.org/10.3390/plants9121804

Rajičić V, Popović V, Terzić D, Grčak D, Dugalić M, Mihailović A, Grčak M, Ugrenović V (2020): Impact of Lime and NPK Fertilizers on Yield and Quality of Oats on Pseudogley Soil and their Valorisation. Notulae Botanicae Horti Agrobotanici Cluj-Napoca. 48 (4): 2134-2152.

Rechcigl JE, Wolf DD, Reneau RB, Kroontje W (1985): Surface Lime Influence on No-Till Alfalfa Grown in an Acid Soil. In: Hargrove et al (Eds.), 1985 Southern Region No-Till Conference, Griffin, Georgia, USA, 112116.

Robson AD, Bottomley PJ (1991): Limitations in the use of legumes in agriculture and forestry. In Dilworth M.J., Glenn A.R. (Eds) „Biology and biochemistry of nitrogen fixation". Elsevier: Amsterdam, the Netherlands, 320-349.

SAS/STAT (2000): User's Guide, Version 9.1.3. SAS Institute Inc.
Stevović V, Lazarević B, Đurović D, Beković D, Tomić D (2010): Bioamass yield and quality of alfalfa cultivars grown on pseudogley. 45 th Croatian and 5th International Symposium on Agriculture, 15-19.2.2010, Opatija, Croatia, 930- 934.

Terzic D, Đekić V, Jevtic S, Popovic V, Jevtic A, Mijajlovic J, Jevtic A (2018): Effect of long term fertilization on grain yield and yield components in winter triticale. The Journal of Animal and Plant Sciences.28 (3): 830836.

Terzić D, Malić N, Popović V, Ikanović J, Rajičić V, Popović S, Jakšić S, Lončarević V (2019): Effects of long-term fertilization on yield of siderates and organic matter content of soil in the process of recultivation. The Journal of Animal and Plant Sciences, 29 (3):790-795.

Zhang XG, Garnett T, Davies K, Peck D, Humphries A, Auricht G (2004): Genetic evaluation and improvement of acid stress tolerance in lucerne breeding: In: Fischer T. et al (Eds.), Handbook and Abstacts for 4th International Crop Science Congress. Brisbane, Australia. 26.

Zhang X, Humphries A, Auricht G (2006): Plant parameters identified for evaluating varietal performance of acid tolerance in lucerne. 13th Australian Agronomy Conference, 10-14.

Ugrenović V, Filipović V, Jevremović S, Marjanović-Jeromela A, Popović V, Buntić A, Delić D (2019): Effect of Brassicaceae as cover crops. Selekcija i semenarstvo, 25 (2): 1-8.

Vasileva V, Kostov O (2015): Effect of mineral and organic fertilization of alfalfa on some seed yield characteristics, root biomass accumulation and soil humus content. Acta Agriculturae Serbica, 20 (39): 51-651. 


\title{
UTICAJ MELIORATIVNIH MERA NA PRODUKTIVNOST LUCERKE NA KISELOM ZEMLJIŠTU TIPA VERTISOL
}

\author{
Jelena Stojiljković, Vera Rajičić, Dragan Terzić, Vuk Radojević, \\ Nenad Đurić, Nataša Ljubičić, Vera Popović
}

\begin{abstract}
Sažetak
Lucerka je najvažnija leguminoza za ishranu stoke u našim agroekološkim uslovima. $\mathrm{Na}$ području Jablaničkog okruga lucerka zauzima značajno mesto u ukupnoj biljnoj proizvodnji. Ograničavajući faktor u formiranju i kratkom veku trajanja lucerke je nizak pH obradivog poljoprivrednog zemljišta. U trogodišnjem terenskom istraživanju zemljišta tipa Vertisol $(\mathrm{pH} \mathrm{u} \mathrm{KCl}$ 4,9) od 2016. do 2018. godine analiziran je prinos lucerke na parcelama sa različitim varijantama prihrane.

Rezultati istraživanja ukazuju da lucerka daje znatno veći prinos na parceli na kojoj su primenjene mere sanacije melioracije, primenom krečnjaka i stajskog đubriva uz dodatak mineralnog đubriva. Nešto niži prinos postignut je na parceli na kojoj je zemljište kalcifikovano i sanirano stajskim đubrivom, dok je najmanji prinos postignut na kontrolnoj parceli, gde je primenjena veća količina mineralnog đubriva, što je zapravo uobičajena praksa poljoprivrednih proizvođača Jablaničkog okruga.
\end{abstract}

Ključne reči: kalcizacija, kisela zemljišta, Medicago sativa L., prinos

Primljen: 18.03.2021.

Prihvaćen: 20.04.2021. 